\title{
Green Information Technology Readiness Model Using Factor Analysis Method In Indonesia
}

\author{
Wahyu Sardjono ${ }^{1}$, Widhilaga Gia Perdana ${ }^{2}$ \\ ${ }^{1}$ Information Systems Management Department, BINUS Graduate Program - Master of \\ Information Systems Management, Bina Nusantara University, Jakarta, Indonesia 11480 \\ wahyu.s@binus.ac.id \\ ${ }^{2}$ Post Graduate Program of Environmental Science, School of Environmental Science, \\ University of Indonesia, Jakarta INDONESIA 11480 \\ Widhilaga.gia@ui.ac.id
}

Received: September 1 ${ }^{\text {th }}, 2019 /$ Accepted: September 29 ${ }^{\text {th }}, 2019$

\begin{abstract}
Green information technology has been increasingly becoming a strategic consideration for developing sustainable business practices through balancing economic and environmental performance of an organization. To help individual organizations better pursue green information technology, this paper presents a factor analysis based decision model for evaluating the green information technology readiness of an organization. The decision model effectively considers the multi-dimensional nature of the evaluation problem and appropriately handle the subjectivity and imprecision of the human evaluation process. An example is given for demonstrating the applicability of the model for evaluating the green information technology readiness of organization. Green information technology readiness is considered to be an organization's capability to embed sustainability in the beliefs and attitudes in the development, deployment and disposal of information technology technical assets and in their information technology processes, practices and policies and in the governance systems to ensure compliance with internal and external sustainability expectations.
\end{abstract}

Keywords: green information technology, factor analysis, readiness model

\section{INTRODUCTION}

The rising costs of doing business in an Information Technology (IT) environment and stronger international commitment to reduce greenhouse gas emissions (GHG) and achieve other environmental goals is bound to create pressure to find ways of achieving greater efficient use of energy and other resources while sustaining economic growth (Alexandra Klimova, et. al., 2016). Green IT has been used to have the ability to attain the sustainability. It has been known with different names amongst different people and places ence leading to a lack of standard agreed upon definition. Some perceive it to be green IT while other called green computing and still others refer to it as green information systems (Cesar Bandera, et. al., 2018). It's important for people to understand what Green IT is, for businesses to engage with it, and for our decision makers to be aware of its consequences and potential in helping us get to a sustainable world (Harijanti, 2015). Unfortunately there is disparity in the level of green IT understanding, causing confusion within the human personnel (Hwang, 2017).

This lack of completely agreed upon definition makes it difficult to measure the effectiveness or the extent of an organisation's implementation of Green IT (Kumar, et. al., 2016). Taken from the broad-view, green IT involves business innovative practices that enhance the recognition of organizational situations (Shahla, 2016) and a company's adaptation to the external dynamics with the use of IT. It takes in to consideration the IT 
personnel capacity for it. Green IT is used for overlapping concepts such as virtualization, recycling, telecommuting, hardware right sizing, energy efficiency and power management among others. The aspiration of Green IT is focused on achieving higher energy efficiency in the use of IT devices and to increase the utilization of already installed devices like servers in data centers. It is a way towards more environment friendly and cost-effective use of power and production technology (Alexandra Klimova, et. al., 2016). A broad definition needs to take into account the challenge within the IT personnel capacity in implementing the latest emerging technologies such as virtualization that can be used to achieve energy efficient data centers through the provision of different solutions like live migration, server consolidation, data deduplications, energy efficiency measurements and green metrics to overcome IT inefficiencies. Server consolidation helps in implementing green data centers to ensure that IT infrastructure hardly contributes to the emission of green house gases while at the same time helping to regain power and cooling capacity, recapturing resilience and dramatically reducing energy costs and total cost of ownership. For the purpose of this study green IT will be considered to be the systematic application of ecological-sustainability criteria to the design, production, sourcing, use and disposal of IT technical infrastructure as well as within the IT personnel in order to reduce IT, business process and supply chain related emissions, waste and water use; improving efficiency and generate green economic rent.

\section{RESEARCH METHODOLOGY}

The conceptual foundation of the green IT readiness framework is drawn from the theories of sustainability, the natural resource-based view, the resource-based view of IT and E-readiness. Each of these areas is reviewed next. Sustainability is an often used but less understood concept. In relation to environmental sustainability, a number of concepts are often used interchangeably. These include Green, eco-sustainable, and environmentally friendly. A full review of these concepts is out of the scope of this article. refers to ecologically sustainable use Green to describe firms, products, and production processes that use less energy, that recycle materials, that reduce waste and pollution, and that preserve natural resources. Yet, Green, when viewed from the sociohistorical perspective, refers to the pro-environmental movement that symbolizes a general reaction toward the fracture in the Western social formation; its economy, security systems, social structures, and traditions (Cesar Bandera, et. al., 2018). Table 1. summarizes the key concepts and definitions extracted from the sustainability literature in light of its relevance to the Green IT Readiness construct.

IT, both as a source of problem and solution, is increasingly becoming linked to eco-sustainability. Each stage of the IT lifecycle from manufacturing to usage and disposal has deleterious environmental impact. Therefore, both IT hardware manufacturers and firms using IT need to apply principles of pollution prevention, product stewardship, and use of clean technologies in managing IT. IT can also be deployed to prevent pollution, improve product stewardship, and facilitate sustainable development (Makarechi, 2010). In this article, consistent with our organizational focus, we draw from the IT infrastructure and capability perspective to conceptualize IT. 
Table 1: Summary of Key Sustainability Concepts

\begin{tabular}{|c|c|c|}
\hline Concept & Definition & Relevance to G Readiness \\
\hline Sustainability & $\begin{array}{l}\text { Meeting the needs of the present } \\
\text { world, without compromising } \\
\text { the ability of future generation to } \\
\text { meet their own needs }\end{array}$ & $\begin{array}{l}\text { Provides the conceptual foundation on the } \\
\text { role of IT in sustainable development and } \\
\text { position the G-readiness construct within } \\
\text { the IT and sustainable development } \\
\text { equation. }\end{array}$ \\
\hline $\begin{array}{l}\text { Triple Bottom } \\
\text { Line }\end{array}$ & $\begin{array}{l}\text { The consideration of economi } \\
\text { cal, social, and environmental } \\
\text { dimensions in measuring orga } \\
\text { nizational sustainability. }\end{array}$ & $\begin{array}{l}\text { The concept of triple bottom line and the } \\
\text { triadic nature of economical, social, and } \\
\text { environmental performance imply that } \\
\text { even if G-readiness is primarily concemed } \\
\text { with the eco-sustainability of IT, it will } \\
\text { have impact on the economical and } \\
\text { societal value of IT. }\end{array}$ \\
\hline $\begin{array}{l}\text { Natural } \\
\text { Resource } \\
\text { Based Theory }\end{array}$ & $\begin{array}{l}\text { Defines eco-sustainability as a } \\
\text { firm's relationship with the } \\
\text { natural environment in relation } \\
\text { to three strategies: pollution, } \\
\text { prevention, product stewardship, } \\
\text { and clean technologies. }\end{array}$ & $\begin{array}{l}\text { The concepts of pollution prevention, } \\
\text { product stervardship, and use of clean } \\
\text { technologies can be applied in defining } \\
\text { what it means to green IT and to use IT to } \\
\text { green the rest of the enterprise. }\end{array}$ \\
\hline $\begin{array}{l}\text { Sustainability } \\
\text { Transformation }\end{array}$ & $\begin{array}{l}\text { Explains sustainability trans } \\
\text { formation and why and how } \\
\text { organizations become greener. }\end{array}$ & $\begin{array}{l}\text { Factors such as sustainability champions, } \\
\text { governance, and policy-setting assist our } \\
\text { understand ing of why and how } \\
\text { organizations become greener. }\end{array}$ \\
\hline $\begin{array}{l}\text { Lifecycle } \\
\text { approach }\end{array}$ & $\begin{array}{l}\text { Considering environmental im } \\
\text { pacts from raw material sourcing } \\
\text { through product design and } \\
\text { development processes to distri } \\
\text { bution and end of life manage } \\
\text { ment. }\end{array}$ & $\begin{array}{l}\text { This means an organization's view of } \\
\text { greening IT needs to be expanded to } \\
\text { reflect the entire IT lifecycle from } \\
\text { creation, through sourcing, to disposing. }\end{array}$ \\
\hline
\end{tabular}

The speed with which environmental sustainability impacts IT infrastructure requires a construct that not only accounts for factors enabling the spread and usage of Green IT, but also explicitly considers the roles played by key enterprise stakeholders. This leads to a question: How do enterprises succeed in greening their IT? We argue that as much as e-readiness has been and still continues to be a critical attribute to succeed in the digital economy, G-readiness could be a critical capability to succeed in the low-carbon digital economy. The following section offers a review of the readiness (e-readiness) concept.

Table 2: Summary of Concepts from the IT Infrastructure and Capability Perspective

\begin{tabular}{|l|l|l|}
\hline \multicolumn{1}{|c|}{ Concept } & \multicolumn{1}{|c|}{ Definition } & \multicolumn{1}{c|}{ Relevance to G-readiness } \\
\hline $\begin{array}{l}\text { IT Technical } \\
\text { Infrastructure }\end{array}$ & $\begin{array}{l}\text { The physical IT and communications } \\
\text { resources of an organization, along } \\
\text { with the shared services and business } \\
\text { applications. }\end{array}$ & $\begin{array}{l}\text { Provides a basis for defining the IT } \\
\text { technical assets of an organization that } \\
\text { can be transformed to a greener IT. }\end{array}$ \\
\hline $\begin{array}{l}\text { IT Human } \\
\text { Infrastructure }\end{array}$ & $\begin{array}{l}\text { The experiences, competencies, } \\
\text { the IT personnel delivering the IT } \\
\text { products and services. }\end{array}$ & $\begin{array}{l}\text { Provides a basis for identifying and } \\
\text { defining the necessary environmen } \\
\text { tally-based behaviors of IT people in } \\
\text { the transformation to a greener IT. }\end{array}$ \\
\hline $\begin{array}{l}\text { IT Managerial } \\
\text { Capability }\end{array}$ & $\begin{array}{l}\text { The management of all IT activities } \\
\text { including strategic foresight concerm } \\
\text { ing changes in the business, IT and } \\
\text { wider environment. }\end{array}$ & $\begin{array}{l}\text { Provides a basis for identifying and } \\
\text { defining the IT managerial capability } \\
\text { needed to transform toward a greener } \\
\text { IT. }\end{array}$ \\
\hline
\end{tabular}

\section{E-Readiness and Capability}

Although the construct of readiness can be traced in organizational change, Information Systems, business process reengineering (BPR) and innovation literature, it has become popular in the e-commerce and egovernment literature. Several researchers have used the readiness or e-readiness construct in empirical studies. 
Table 3: Summary of Concepts from E-Readiness and Capability Perspective

\begin{tabular}{|l|l|l|}
\hline \multicolumn{1}{|c|}{ Concept } & \multicolumn{1}{|c|}{ Definition } & \multicolumn{1}{c|}{ Relevance to G-readiness } \\
\hline E-readiness & $\begin{array}{l}\text { Refers to critical human, technological } \\
\text { and managerial capacities required to } \\
\text { transform to e-business and to execute } \\
\text { in the e-economy successfully. }\end{array}$ & $\begin{array}{l}\text { Provides a solid framework to under } \\
\text { stand organizations capacity to trans } \\
\text { form towards a greener IT and help to } \\
\text { identify some of the important varia } \\
\text { bles necessary for such tranns } \\
\text { transformation. }\end{array}$ \\
\hline $\begin{array}{l}\text { Organizational } \\
\text { Capabilities }\end{array}$ & $\begin{array}{l}\text { Capabilities represent firms }{ }^{4} \text { ability at } \\
\text { acquiring, coordinating, and deploying } \\
\text { resources. Capabilities can be input-, } \\
\text { transformation, and output-based. }\end{array}$ & $\begin{array}{l}\text { Offers a theoretical foundation to } \\
\text { anchor G-readiness as the permeation } \\
\text { of eco-sustainability principles in a } \\
\text { ompany's IT input, transformation } \\
\text { and output capabilities. }\end{array}$ \\
\hline Maturity & $\begin{array}{l}\text { A framework that maps a firm's } \\
\text { development through various stages } \\
\text { over time until it reaches the highest } \\
\text { level of perfection. }\end{array}$ & $\begin{array}{l}\text { The G-readiness of an organization at } \\
\text { any one time can be considered to be } \\
\text { an assessment of the level of maturity } \\
\text { with respect to Greening IT. }\end{array}$ \\
\hline
\end{tabular}

Source : Molla, Alemayehu; Cooper, Vanessa; and Pittayachawan, Siddhi (2011) "The Green IT Readiness (G-Readiness) of Organizations: An Exploratory Analysis of a Construct and Instrument," Communications of the Association for Information Systems: Vol 29 , Article 4.

At a global scale, the World Economic Forum publishes its annual report on the Network Readiness\| of countries. Two dimensions of the e-readiness construct can be identified in the literature. The first refers to readiness as a precursor condition (or set of conditions) for the implementation of initiative such as a change, IS or innovation. The second refers to readiness as a capability of a business that needs constant building, rebuilding and upgrading. 
Table 4. Rersearch Instrument Development

\begin{tabular}{|c|c|c|c|}
\hline Construct & Indicator & Reference & Statement \\
\hline Green IT & $\begin{array}{l}\text { sustainable } \\
\text { concems. }\end{array}$ & $\begin{array}{l}\text { Alexancira Klimova, Bric Rondean, Karl } \\
\text { Andersion, Jari Porra, Andrei Rrbin, Arkady } \\
\text { Zaslavairy. 2016. An international Master's } \\
\text { program in green IT as a contribution to } \\
\text { sustainabie development Joumal of Cleaner } \\
\text { Production. Elsevier. }\end{array}$ & $\begin{array}{l}\text { green IT is important in } \\
\text { ensuring further IT develop } \\
\text { ment around suatainability } \\
\text { concerns. }\end{array}$ \\
\hline $\begin{array}{l}\text { Green IT } \\
\text { Readines5 }\end{array}$ & Rostamare & $\begin{array}{l}\text { Shahla, Ab Razak CheHussin, Halima } \\
\text { MohamedDahlan. 2017. Organizational rese } \\
\text { arch in the freid of Green } I T \text { : A systematic } \\
\text { Iiteratwre review from 2007 to 2016. Telematics } \\
\text { and Informatica. Vol 34, Issue 7. November } \\
\text { 2017. Pages 1191-1249. Elsevier. }\end{array}$ & $\begin{array}{l}\text { The organization need a } \\
\text { roadmap to guide future } \\
\text { studies on Green IT and } \\
\text { highlight directions for the } \\
\text { successful implementation of } \\
\text { Green IT. }\end{array}$ \\
\hline $\begin{array}{l}\text { Green IT } \\
\text { Attitude }\end{array}$ & $\begin{array}{l}\text { education } \\
\text { technology }\end{array}$ & $\begin{array}{l}\text { Ceaar BanderaRegina Collins, Katia Passeri ni } \\
\text { 2018. Rishy business: Experiential lean ing, in } \\
\text { formation and communications techno logy, and } \\
\text { risk-taking attinudes in entrepreneur ship } \\
\text { education International Joumal of Management } \\
\text { Education Blsevier. }\end{array}$ & $\begin{array}{l}\text { This work helps bridge } \\
\text { entrepreneurahip education } \\
\text { and education technology by } \\
\text { constructing and empirically } \\
\text { testing a model relating } \\
\text { entrepreneurial characteris tics } \\
\text { and IT attitudes. }\end{array}$ \\
\hline $\begin{array}{l}\text { Green IT } \\
\text { Policy }\end{array}$ & green damage & $\begin{array}{l}\text { Kumar, M., Raman, J.and Priya 2016. 'The } \\
\text { effects of green policy on the performance of } \\
\text { green supply chains', Int. J Integrated Suppty } \\
\text { Managemerit, Vol.10, No.1, p.1-37. }\end{array}$ & $\begin{array}{l}\text { effects of green policy on the } \\
\text { performance of green supply } \\
\text { chains is benefit enhancing } \\
\text { when the levels of green } \\
\text { damage caused by pollution. }\end{array}$ \\
\hline $\begin{array}{l}\text { Green IT } \\
\text { Governance }\end{array}$ & $\begin{array}{l}\text { public } \\
\text { participation. }\end{array}$ & $\begin{array}{l}\text { Hanjanti, S.D. 2015. 'The changing paradigm on } \\
\text { governance: the case of Indonesia'. Int.J. Public } \\
\text { Lan and Poitcy, Vol 5. No. 1, pp. } 77-91 \text {. }\end{array}$ & $\begin{array}{l}\text { The govemance system bas } \\
\text { been transformed to be more } \\
\text { accommodative to public } \\
\text { participation. }\end{array}$ \\
\hline $\begin{array}{l}\text { Green IT } \\
\text { Practice }\end{array}$ & $\begin{array}{l}\text { organisational } \\
\text { culture }\end{array}$ & $\begin{array}{l}\text { Hwang. T. and Kim, S.T. 2013. 'The mode } \\
\text { rating effects of eco-ori ented organisational } \\
\text { culture on the green practice-performance relati } \\
\text { onghip', Int J. Services Sciences, Vol. 5. No. } 1 \text {. } \\
\text { pp. } 74-94 \text {. }\end{array}$ & $\begin{array}{l}\text { clearly eatabliah a strategic } \\
\text { vision from an environ mental } \\
\text { perspective, based on a } \\
\text { company-wide collabora tive } \\
\text { effort. }\end{array}$ \\
\hline $\begin{array}{l}\text { Green IT } \\
\text { Technology }\end{array}$ & $\begin{array}{l}\text { green } \\
\text { technologies }\end{array}$ & $\begin{array}{l}\text { Makarechi, S. and Yerushalmi, L. 2010. 'Shades } \\
\text { of green technologi es:id entification of } \\
\text { significant para meters affecting the Performance } \\
\text { of green technologies in buildings". Int J. } \\
\text { Environmental Policy and De cision } \\
\text { Making,Vol.1.No.1,p.64-76. }\end{array}$ & $\begin{array}{l}\text { shades of green technolo gies' } \\
\text { is offered to reflect the } \\
\text { potential for 'scaling' or gre } \\
\text { ding of 'green' in building } \\
\text { construction projects. }\end{array}$ \\
\hline
\end{tabular}

The combination of the eco-sustainability, IT infrastructure, and e-readiness perspectives offer useful insights in conceptualizing G-readiness. As more organizations become concerned with Green IT, there is a need to understand their capability for implementing and sustaining Green IT strategies and polices.

\section{RESULTS AND DISCUSSIONS}

Based on test validity and reliability of 26 the questions by using Cronbach's alpha, researchers gain coefficient alpha of 0.928 . From these results it can be concluded that the value of the data from all of the variables used is reliable. In the factor analysis, the researchers take measurements variant on all factors which are using Eigen values greater than 1. By using Eigen values than 1 has formed 6 (six) new factor of the analysis results with the cumulative result of the extraction variant of $82.71 \%$. At Table 5 . This value is obtained from the sum percentage of the overall variance components as follows: 
Table 5. Cumulative value per Extraction Factor

\begin{tabular}{|c|c|}
\hline xtraction Number & Cumulative $\%$ \\
\hline 6 & 82,71 \\
\hline 5 & 78,31 \\
\hline 4 & 72,89 \\
\hline 3 & 64,20 \\
\hline 2 & 54,99 \\
\hline
\end{tabular}

Source: Research Analysis (2017)

Based on these data, the authors continued analysis by extracting a factor until the remaining 4 (four) factors to which factors have a better and decent distribution with cumulative score of $72.88 \%$ for further analysis because it has met the criteria. After knowing the form factor is 4, then make determinations of each independent variable will be entered into each factor by looking at the table Component Matrix of output results factor analysis is used. Once that is done the rotation of the independent variables. Determining variable to a particular factor by the magnitude of correlation between variable factors, that is, to which the correlation is greater. Thus the new factor, which is made up of indicators collected, among others:

The new first Factor $\left(\mathrm{X}_{1}\right)$ is Security System, as represented of colaborations:

1. Delivery of data by using sustainability influence on green IT readiness compared with no current systems condition.

2. The issue of the security of the data circulating in the digital and global world as the era of the cloud is now a matter that should receive special attention from the company.

3. A management controls are necessary to ensure that green IT Policy the same as the governance that have been designated as what is sent, or data/files which are located on the delivery system.

4. Controlled delivery system files provides the ability to track the entire process of delivery along with authenticity.

5. There are many companies or divisions of companies who do not heed the compliance of the process of sending an information/data/files and prefer to use a public sharing such as Dropbox or use email for sending data.

6. An integrated system capable of providing complete and accurate infromasi so output appropriate information useful in the work of the user.

7. Use file systems delivery manager can reduce the burden of hidden costs and increase the chances of the company to increase its revenues.

8. Utilization compression feature generates a significant acceleration of the process of sending files.

The new second Factor $\left(\mathrm{X}_{2}\right)$ is Business Support System, as represented of colaborations:

1. Utilization of IT in organizations even companies sometimes be an additional burden in running the business so that the customer should be charged.

2. Ease of access to information needed to effectively and efficiently be a significant key in producing exceptional quality of service.

3. This level of integration of the IT and process controls can be a business advantage aspire to total quality and business excellence

4. Visibility of the entire business process to the file exchange process is the basis for the company responsible for the corporate governance there..

5. In order to maintain control and compliance companies should be able to provide a complete record of information related to who is accessing data/files and also what to do when such access.

6. The integration process almost always involves a file transfer, a process that, if not handled properly can delay the project or cause the implementation of operational failure or even loss.

The new third Factor $\left(\mathrm{X}_{3}\right)$ is Systems Weaknesses, as represented of colaborations:

1. Organizations need reliable information systems that enable analysis and access to the right information to make effective decisions.

2. Ease of learning to a new system is able to add its own motivation for employees to use.

3. Usage-based automated information systems in the enterprise can improve the efficiency and effectiveness of communication in organizations that help in the decision.

4. Use of IT such as the Internet in running business processes can increase productivity levels and employee performance. 
5. Utilization of specific protocols typically have an influence at the time of moving large amounts of data or files.

6. Centralized management approach helps companies to focus on learning and management systems.

The new forth Factor $\left(\mathrm{X}_{4}\right)$ is Systems Comfortable Usage, as represented of colaborations:

1. Professional training in a company can influence the level of turnover of employees.

2. IT Strategy, vision, and mission has become an important part of the company's business strategy.

3. Users of the system are more satisfied using a system that has a higher effectiveness compared to a system less effective.

4. Process automation in the enterprise can improve security and reduce human error.

5. Implementation of an application supporting the running process of sending data to increase efficiency, especially for large amounts of data.

6. Data integrity can be met with the use of a specific protocol to improve security at the file delivery process.

After a thorough analysis of the factors, it was found that there is a data reduction where there is a proper screening process components into new indicators and factors. Factors used to evaluate the performance of the systems formed from the results of factor analysis is the safety factor systems, IT support the business, ability/capability of the system, as well as the convenience of using systems. To know more dominant factor of four factors above, it must be done regression between these factors with the level of understanding of respondents to the systems in a company that has been obtained from the questionnaire.

After doing the regression will get down to the value of each factor to perform the calculation model as follows:

$$
\mathbf{Y}=\mathbf{B}_{0}+\mathbf{A}_{1} \mathbf{X}_{1}+\mathbf{A}_{2} \mathbf{X}_{2}+\mathbf{A}_{3} \mathbf{X}_{3}+\mathbf{A}_{4} \mathbf{X}_{4}
$$

With the values obtained from the regression of these factors with the understanding of the respondents, the results obtained values as follows:

$$
\begin{aligned}
& \mathrm{B}_{0}=6.697 \\
& \mathrm{~A}_{1}=0.135 \\
& \mathrm{~A}_{2}=0.006 \\
& \mathrm{~A}_{3}=-0.384 \\
& \mathrm{~A}_{4}=0.128
\end{aligned}
$$

So as to built a model of the green IT readiness results as follows:

With ranges:

$$
Y=6.697+0.135 X_{1}+0.06 X_{2}-0.384 X_{3}+0.128 X_{4}
$$

$$
\begin{aligned}
& -2.338 \leq X_{1} \leq 1.546 \\
& -2.063 \leq X_{2} \leq 2.017 \\
& -1.742 \leq X_{3} \leq 2.388 \\
& -2.054 \leq X_{4} \leq 1.155
\end{aligned}
$$

From the above model, the first component $\left(\mathrm{X}_{1}\right)$ are interpreted as 'Threat Systems' positive value 0.135. This means improvement and special attention to the factors $X_{1}$ will have a positive impact on the level of understanding of respondents to the system so that it can improve the performance of the systems as well. $\mathrm{X}_{1}$ factors influenced by indicators indicators associated with factors of safety, as in figure 3 . These factors include indicators of security measures such as encryption of data, control data flow, regulation of data flow, motion tracking data, and so greatly affect green IT readiness itself, where if these indicators increased (positive movement) then the users will experience increased understanding of the function of the actual systems and assess that the system works in accordance with the existing IT strategic direction and eventually also affect green IT readiness and IT division of the company in general. Description of the managerial implications, based on the minimum and maximum values of each factor is found, it will obtain the value of evaluation as follows In the Table 6 . can be seen in the user's understanding of the green IT readiness:

1. The current conditions, where there is no change in either addition or subtraction on new factors were found, so the evaluation of the value of understanding the use of the application system has a value of 6.697 if quantified the user's understanding of the green IT is currently sufficient.

2. A minimum condition, in which all factors were found to decrease from the current state to look at their lowest point, so the evaluation value of the user's understanding of the system and the green IT readiness and 
has a value of 6.775 then if quantified understanding at the highest point to be good or very good compared to current conditions.

3. The maximum condition, in which all factors were found to be increased from the current state to see its highest point, so the evaluation value of the user's understanding of the green IT readiness and has a value of 6.337 then if quantified understanding of users of the system to be bad or very bad in comparison with the current conditions.

4. The extreme conditions, where all the negative factors were found to be lowered to the minimum point of the current conditions and found to be negative factors that increased the maximum at its highest point, so the green IT readiness of the user's understanding of the system and the value green IT readiness and has a value of 5.224 then if quantified understanding users of the readiness to be bad or very bad compared to current conditions.

5. The ideal conditions, all factors were found to positively enhanced the maximum at its highest point, and found to be negative factors derived from the current state to the minimum point, so the evaluation value of the user's understanding of the system and the green IT readiness and has a value of 7,887 then if quantified understanding at the highest point to be good or very good compared with the current conditions.

\begin{tabular}{|c|c|c|c|c|c|c|}
\hline Simulation & $\mathbf{y}$ & $B_{0}$ & $\mathrm{X}_{1}$ & X, & $\mathbf{y}_{2}$ & $\mathbf{x}$ \\
\hline Current & 6.697 & 6,697 & 0 & 0 & 0 & 0 \\
\hline Minimum & 6,775 & 6,697 & $-2,338$ & $-2,063$ & $-1,742$ & $-2,054$ \\
\hline Maximum & 6,337 & 6,697 & 1.546 & 2,017 & 2,295 & 2,350 \\
\hline Extreme & 5,224 & 6,697 & $-2,338$ & $-2,063$ & 2,295 & $-2,054$ \\
\hline Ideal & 7,888 & 6,697 & 1,546 & 2,017 & $-1,742$ & 2,350 \\
\hline
\end{tabular}

\section{CONCLUSION}

Based on research by the factors that affect green IT readiness, among others: Security Systems, Support Systems in Business, Systems Weaknesses, and Comfortable Systems Usage. At the factors found above, there are indicators of supporters who formed the occurrence of these factors, namely 'Security System' consisting of indicator data encryption, data compression, security of data traffic, control flow and data types, tracking the flow of data, the accuracy of the process, regulatory compliance and operational costs. Then factor 'in the System Support Business' consisting of indicators ease of data access, integration and control of business processes, business process visibility, recording and controlling system, the integration of data transfer. A further factor "System Weaknesses" which consisted of a quick indicator of response and system reliability, ease to learn, decision-making, increased productivity, a special protocol, and centralized systems approach. The last factor is the Comfort Using Systems' consisting of professional training indicators, support the IT strategy, user satisfaction, automation systems, the efficiency of IT resources, and integration of data processing systems. Models are formed from the discovery of new factors on the green IT readiness by entering the value of the influence of these factors, it will be found an evaluation model as follows:

$$
Y=6.697+0.135 X_{1}+0.006 X_{2}-0.384 X_{3}+0.128 X_{4}
$$

With ranges:

$$
\begin{aligned}
& -2.338 \leq X_{1} \leq 1.546 \\
& -2.063 \leq X_{2} \leq 2.017 \\
& -1.742 \leq X_{3} \leq 2.388 \\
& -2.054 \leq X_{4} \leq 1.155
\end{aligned}
$$

\section{REFERENCES}

Alexandra Klimova, Eric Rondeau, Karl Andersson, Jari Porras, Andrei Rybin, Arkady Zaslavsky. (2016). An international Master's program in green IT as a contribution to sustainable development. Journal of Cleaner Production. Elsevier. 
Cesar Bandera, Regina Collins, Katia Passeri ni. (2018). Risky business: Experiential learn ing, in formation and communications techno logy, and risk-taking attitudes in entrepreneur ship education. International Journal of Management Education. Elsevier.

Harijanti, S.D. (2015). 'The changing paradigm on governance: the case of Indonesia', Int.J. Public Law and Policy, Vol. 5, No. 1, pp.77-91.

Hwang, T. and Kim, S.T. (2013). 'The mode rating effects of eco-ori ented organisational culture on the green practice-performance relati onship', Int. J. Services Sciences, Vol. 5, No. 1, pp.74-94.

Kumar, M., Raman, J.and Priya. (2016). 'The effects of green policy on the performance of green supply chains', Int. J. Integrated Supply Management, Vol.10, No.1, p.1-37.

Makarechi, S. and Yerushalmi, L. (2010). 'Shades of green technologi es:id entification of significant para meters affecting the Performance of green technologies in buildings', Int. J. Environmental Policy and De cision Making,Vol.1,No.1,p.64-76.

Shahla, Ab Razak CheHussin, Halina MohamedDahlan. (2017). Organizational rese arch in the field of Green IT: A systematic literature review from 2007 to 2016. Telematics and Informatics. Vol. 34, Issue 7, November 2017, Pages 1191-1249. Elsevier. 